\section{FDA to regulate tissue banks}

research or educational purposes.

Where cells and tissues are used for their normal functions and processing is minimal, the only submissions required will be registration, product listing and adverse event reports. Where cells and tissues are processed to alter their normal biological function, the FDA will require clinical trials to prove they are safe and effective. This applies to cells and tissues combined with drugs or medical devices, as well as products using forms of somatic or stem cell therapy, or gene therapy.

Industry supports registration. "It's something we've been requesting for about 15 years," says Jeanne Mowe, executive director of the American Association of Tissue Banks. "You have to know who the players are in order to operate in an intelligent fashion."

The value of the industry is estimated at $\$ 500$ million and it has changed dramatically in the last decade, growing from a handful of banks affiliated with hospitals to an industry of at least 150 companies, many of them profit-motvated. The world's largest nonprofit tissue bank Musculoskeletal Transplant Foundation, New Jersey, estimates that uses for human body parts have climbed to more than 650 .

Tom Hollon, Bethesda

\title{
New reporting rules for gene therapy and xeno trials
}

The United States Food and Drug Administration (FDA) has proposed new regulations that would require rapid public disclosure of adverse events both from corporate and academic trials of gene therapy and xenotransplantation. Consumer groups have applauded the proposal, but industry representatives and bioethicists are concerned that the new rules are poorly framed, and could set a dangerous precedent. Currently, such public disclosure is only required for government-funded trials.

The rule change was inspired by the controversy surrounding the 1999 death of Jesse Gelsinger in a gene therapy trial at the University of Pennsylvania, in which it was questioned whether more open reporting of adverse events may have helped to avoid the tragedy (Nature Med. 6, 235; 2000).

But experts outside the FDA argue that, far from representing a comparable risk, the two technologies are fundamentally different and should be regulated separately. Unlike gene therapy, xenotransplantation has not yet entered the clinical trial stage. "Xenotransplantation has its own intrinsic challenges, worries and risks, and these need to be handled on their own," insists Harold Vanderpool, a bioethicist at the University of Texas Medical Branch and a member of the FDA's advisory subcommittee on xenotransplantation. Vanderpool adds that the agency did not consult the subcommittee in formulating the proposed rules.

Representatives of the biotechnology industry also object to the proposal, citing the danger of accidentally disclosing confidential patient information or proprietary corporate data. "We think that the new rules are a deviation from decades of regulatory practice and law at the FDA," says Charlie Craig, bioethics counsel for the Biotechnology Industry Organization (BIO). BIO representatives also worry that the new rules could set a precedent that could be applied to all types of clinical trials in the future.

In addition to BIO, one group likely to weigh in on the issue is the newly formed Secretary's Advisory Committee on Xenotransplantation (SACX) of the Department of Health and Human Services. The committee will be chaired by Vanderpool and held its first meeting as Nature Medicine went to press. SACX is expected have broad oversight over issues related to xenotransplantation.

Alan Dove, Philadelphia

\section{Limited gene therapy trials to restart}

The fortunes of two controversial gene therapy researchers shifted in late January-one for the worse and one for the better. James Wilson was further sidelined in his role of director of the Institute for Gene Therapy at the University of Pennsylvania, while Tufts University researcher Jeffrey Isner seemed set to get by with a little help from his friends in re-starting at least one gene therapy trial.

The University of Pennsylvania has announced that, as part of its application to the FDA to restart experiments, it has revamped two gene therapy clinical trials and removed them from the purview of James Wilson and his troubled Institute.

Wilson was in charge of the fateful gene therapy trial that resulted in the 1999 death of Jesse Gelsinger (Nature Med. 6, 6, 2000). The teenager died after being injected with genetically altered virus. That case led to the FDA to halt all trials at the Institute and triggered a major debate among researchers and regulators about gene therapy, financial conflicts of interest and patient protections. Wilson is currently facing FDA action that may lead to his being banned for life from clinical experimentation (Nature Med. 7, 6, 2001).

The two trials about to restart-which involve treatments for lung cancer and mesothelioma-were among eight studles that the FDA shut down last year. Wilson will remain Institute director, but his program will instead concentrate on basic research, says University Provost Robert Barchi, adding "... that will be the case for the foreseeable future." Wilson remains a tenured professor.

Further north, a Boston area couple who are friends of Isner have donated \$1 million to St. Elizabeth's Hospital specifically to support his work there. Isner has been allowed to resume one of three gene-therapy trials shut down by the FDA in February 1999. Like Wilson, Isner was charged last winter with failing to protect study participants. For example, the FDA said that he allowed a man with strong evidence of lung cancer into a study that excluded cancer patients. In November, the FDA granted Isner permission to resume one trial, and he says that he also expects to get the green light on the other two studies.

Isner says that he has received a letter from the FDA exonerating him of all charges, but he declined to release the letter at the advice of lawyer. An FDA spokeswoman told Nature Medicine that regulations preclude the agency from commenting on the case.

A proposed FDA rule would broaden public access to agency documents regarding the regulation of gene therapy and xenotransplantation studies.

Tinker Ready, Boston 